\title{
A Critique of Knowledge-Based Economies: A Case Study of Singapore Education Stakeholders
}

Vicente Chua Reyes Jr.

S. Gopinathan

ABSTRACT: This article critically examines the sense-making processes of key stakeholders of Singapore's education: a historically dominant city-state, highlyqualified teachers, and high-performing students. The article interrogates the Teaching Schools Learning Nation policy initiative deployed toward achieving a knowledge-based economy. The article uses micropolitics in exploring issues that stakeholders face in the midst of globalization. Findings from research at the Centre for Research in Pedagogy and Practice at the National Institute of Education support key arguments. In exploring sense-making processes, the article uncovers paradoxical interpretational responses of stakeholders implementing the Teaching Schools Learning Nation policy, providing a critique of the city-state's knowledge-based economy ambitions.

The question we are facing now is, to what extent is the educational endeavor affected by processes of globalization that are threatening the autonomy of national educational systems and the sovereignty of the nation-state as the ultimate ruler in democratic societies? At the same time, how is globalization changing the fundamental conditions of an educational system premised on fitting into a community, a community characterized by proximity and familiarity?

—Burbules and Torres (2000, p. 4)

a

This article interrogates how education stakeholders-defined as a dominant city-state, teachers working in a centralized system, and students operating within a high-stakes testing environment-reinterpret their roles in a planned knowledge-based economy (KBE) enmeshed in the processes of globalization. Globalization, as defined in this inquiry, "represents a complex, overlapping set of forces, operating differently at different levels" (Dale \& Robertson, 2002, p. 11). Furthermore, as an exploration of how stakeholders negotiate complexity, viewing globalization as much more than a process but as a "tendency to which counter-tendencies may be mobilized" provides an appropriate analytical starting point (Hay, 2002, p. 389).

Stakeholders in today's highly interconnected global education context constantly find themselves in the midst of "fundamental disjunctures" (Ap- 
padurai, 1990, p. 6), attempting to make sense of different tendencies of the evolving educational endeavor: international league tables; 21 st-century skills that have to do with creativity and innovation; ${ }^{1}$ national education strategies geared toward international tests, such as the PISA (Program for International Student Assessment), TIMMS (Trends in International Mathematics and Science Study), and PIRLS (Progress in International Reading Literacy Skills); ${ }^{2}$ and reform initiatives premised on international benchmarking, such as the 2001 No Child Left Behind Act of the United States and the 2010 Education White Paper in the United Kingdom-to name just a few of the tendencies that continually shape contested education landscapes.

This inquiry explores how education stakeholders respond to these disjunctures through the use of their "deeply perspectival constructs" (Appadurai, 1990, p. 7). Singapore-consistently identified as one of the top 10 global cities in the world (Hales, King, \& Pena, 2010) and a city-state that has deliberately and carefully planned for itself to become a $\mathrm{KBE}$-provides an interesting case study of how stakeholders respond to the dynamics of globalization. Scholars have already attempted to map the response of the Singapore government, led by the powerful People's Action Party (PAP), ${ }^{3}$ and its choosing to reconfigure itself as a KBE in relation to the forces of globalization. A. Koh (2010) provides an insightful viewpoint by describing the Singapore city-state as an agent actively engaging and anticipating threats and opportunities presented by globalization forces and responding to these with well-thought-out and carefully calibrated experimentation specifically through education policies. Koh refers to this as "tactical globalization" highlighting how the city-state "continues to work with and against globalization" (p. 195) by employing its vast resources in shaping education knowledge and discourse. This inquiry argues that the Singaporean city-state that has carefully fashioned itself as a "globally competitive" KBE (Chia, 2001, p. 170) adheres to a model geared toward "an ideological extension of the neoliberal paradigm of globalization" (Peters, 2001, p. 13). The inquiry further asserts that Singapore's KBE approach pursues a predominantly functionalist perspective in relation to education.

This inquiry extends the analysis of the Singaporean case by introducing perspectival constructs of two other stakeholders. Aside from the city-state as the dominant stakeholder pushing the KBE approach, the analysis also includes teachers practicing facets of their autonomy and students manifesting their evolving identities in actively engaging with the city-state's tactical response to globalization. Specifically, the article explores the sense-making processes of stakeholders as they reinterpret education policies from their perspectival constructs.

Exploring the sense making of different education stakeholders within the dynamics of globalization in Singapore could provide analytical illumination to an emerging aspect of comparative education: issues and challenges faced by stakeholders negotiating a disjunctured landscape forged by the dynamics 
of globalization and, more important, a problematization of the often unquestioned KBE model as seen from stakeholders' experiences.

\section{Negotiating Education Policies Amid Globalization: KBE}

The Singapore government has set the target of becoming a "globally competitive knowledge economy" (Ministry of Trade and Industry, 1998, p. 6). As a response to the pressures to continue "creating national wealth and sustaining economic growth" (Chia, 2001, p. 170) brought on by a rising Asia, Singapore has carefully reconfigured itself to be a KBE. "In the education sector in particular, it has spearheaded among many other initiatives the Global Schoolhouse Project" (Montsion, 2009, p. 640), effectively opening up its shores for international education providers to locate themselves, as well as encouraging its local citizens to pursue educational pathways overseas. These efforts to capitalize on globalization by becoming a KBE seem to have achieved mixed results at best. Alongside its success in becoming acclaimed as one of the world's most globalized nations, Singapore has experienced tensions from increasing income inequalities and their accompanying social consequences, as well as the careful and delicate balance of labor migration and its host of issues. In the still highly centralized Singapore education system, dominated by the powerful PAP government, this inquiry attempts to explore how stakeholders make sense of the challenges of globalization processes. For this exploratory inquiry, certain aspects of micropoliticswhich place emphasis on "relationships rather than structures, knowledge rather than information, skills rather than positions, verbal interaction rather than minutes and memos" (Ball, 1994, p. 3822) — could provide exploratory avenues in discovering stakeholders' sense-making efforts within the vastly changing education policy landscapes. Using micropolitics as an analytical tool provides a nuanced and insightful picture of how policy is interpreted and reinterpreted in Singapore: a strong highly centralized city-state negotiating change in an increasingly unpredictable globalized scenario. The inquiry elaborates on a multilevel analytical framework of stakeholders' tactics and how "they make sense of the overpowering waves of education reform" (Reyes, 2010, p. 397), specifically interpreted within a micropolitical perspective - or their constructions of policy and practice-amid the challenges brought about by the contested forces of globalization. The landmark 1997 Thinking Schools Learning Nation (TSLN) policy—which formed the national education strategy for the 21 st century-and selected empirical findings from national surveys on teachers' and students' pedagogical practices as responses to the TSLN are the starting points for exploring stakeholders' attempts at sense making.

The article is divided into five sections. The first sets the context of globalization and the emerging challenges facing the Singapore city-state. The second section elaborates on the response of the city-state to globalization, 
chiefly through its adherence to a KBE framework. This section provides analytical focus on how the Singapore city-state actively deploys tactical globalization in performing its consistently unapologetic strong role. Through elements of the micropolitical perspective, the third section explores teachers' responses to the globalizing discourse. The fourth section continues to use some elements of the micropolitical perspective to investigate students' responses to the push for globalization. The fifth and final section provides a discussion of insights pertinent to critical education studies.

\section{The Singapore Context and the Emerging Challenges Facing the City-State}

On August 9, 2012, the Republic of Singapore celebrated its 53rd anniversary as an independent state. Quite distant from its unsettled beginnings in 1959-when it was characterized by impoverished slums divided along ethnic lines, rising social tensions, and sporadic racial riots-the nation has undergone a dramatic transformation. As a young and rather fragile nation-state, it pursued a relentless and aggressive agenda toward development, facilitated by the emergence and maintenance of a strong government. Guided by an elite corps of technocrats and leaders, Singapore has been able to amass significant amounts of economic and human capital, earning consistently top rankings as one of the world's most prosperous and competitive nations (World Economic Forum, 2009). Today, the city-state has received accolades as the world's most globalized country ${ }^{4}$ (A. T. Kearney, Foreign Policy, \& Chicago Council for Global Affairs, 2008).

Singapore's response to its history and vulnerabilities has led scholars to characterize it as an "administrative state" (Chan, 1997; K. L. Ho, 2000) or what other commentators describe as a "developmental state" ${ }^{5}$ K. Y. Lee, 1999). Its genesis as a nation was volatile, as it was forcibly separated from Malaysia and it emerged as a reluctant state. Early in its turbulent past, the state realized that social cohesion among its multiethnic population was critical to accomplish nation-building goals.

\section{Education and Economic Policy Combination: Foundation for Singapore's Success}

It can be argued that Singapore's development trajectory-particularly, its strategies in education and the economy-have been pragmatic, deliberate, and, to a certain extent, successful. Notwithstanding debates on the apparently inconclusive linkages of education to macroeconomic growth, the Singapore government has consistently used education as a strategic instrument to accomplish not only economic goals but social cohesion and nation-building objectives as well. Tight coupling of labor market needs with school system outputs, coordinated at the highest levels of government and through the 
efforts of such innovative institutions as the Economic Development Board, has contributed to impressive economic growth and rising standards of living (Ashton, Green, James, \& Sung, 1999). After effectively neutralizing the communist threat, minimizing the "competitive" influence of an opposition, and preventing "mass media from adopting a Western liberal approach," the government successfully engendered a "controversial Singapore style of peaceful environment for the multinational corporations to smoothly manage their business operations" (Chang, 2003, p. 94). As a result, a strong, elite-driven technocratic leadership made economic growth a major priority and, in the process, managed to strengthen social cohesion considerably. Additionally, that the PAP has formed the government since 1959 and has led the city-state since then, all while adhering to the party's pragmatic ethos exemplified in consistent policy formulation and implementation, made the city-state a unique mold of public administration with few parallels elsewhere.

The result of these policies is evident in the country's high-quality physical infrastructure, paying particular attention to ensuring that its housing, transportation sector, and public services complement growth (Phang, 2000). The nation's per capita gross domestic product (GDP) averaged $5.53 \%$ (in 2000 market prices terms) from 1961 to 2006 (K. W. Ho, 2007, p. 47). In 2011, its GDP per capita was US\$50,123 (SGD\$63,050), a real economic growth rate of $4.9 \%$ for the year (Singapore Statistics, 2011a). Such figures provide evidence of the city-state's economic resiliency, taking into consideration the crippling global economic crises that occurred from 2007 to 2009.

The record of the government in terms of its economic performance is complemented by its dedication to investing in upgrading its human capital. For instance, from 1992-1993 to 2006-2007, the government's recurrent expenditure in education averaged an increase of almost 7\% (Ministry of Education [MOE], 2007). ${ }^{6}$ In 2010, the mean years of schooling was 10.1, compared to 9.1 in 2000 (resident nonstudents aged 25 years and over); the literacy rate was a high $95.9 \%$ (residents aged 15 and over); and an impressive $91.7 \%$ of resident nonstudents between 25 and 39 years old possessed secondary and higher educational qualifications (Singapore Statistics, 2011b). Perhaps even more important, the secondary school completion rates for all the ethnic races ${ }^{7}$ in the diverse nation averaged 97\% (MOE, 2009).

A key policy feature of Singapore education has been attention to quantitative and qualitative growth. International benchmarks, such as the TIMSS, PIRLS, and Math and Science Olympiads, provide evidence of a spread of academic achievement within the key ethnic groups of Singapore. The 1996 TIMSS acknowledged Singapore as one of the top-performing countries in third- and fourth-grade mathematics (Mullis et al., 1997) and the bestperforming country in eighth- and ninth-grade science (Beaton et al., 1996). In the 2003 TIMMS, Singapore emerged once again as one of the topperforming countries in fourth- and eighth-grade science and mathematics (Martin, Mullis, Gonzales, \& Chrostowski, 2003), and the PIRLS indicated 
that Singapore was one of the top three performing countries in its 2006 report (Mullis \& Martin, 2007).

\section{New Challenges Facing the Singapore Nation-State}

Notwithstanding global economic uncertainties that occurred from 2007 to 2009, the relentless competing forces of globalization continue to change radically the sociopolitical and economic landscape in the Asia-Pacific region. The efficient administrative system and pervasive control that the government is known for and that accounted much for its economic development may not be appropriate in an increasingly globalized scenario that rewards flexibility, innovation, and ground-up involvement. This is a significant challenge to the Singapore model of an export-driven, multinational corporation-led economy and the type of labor force attributes that went with it.

\section{Threats to Singapore's Economic Niche}

The 2007 economic downturn sparked by the subprime mortgage crisis in the United States has sharpened the dilemmas facing policymakers in Singapore. The constraints are well known-small size, small population, and lack of natural resources save a good location and deep water harbor. While the export-led growth policy was highly successful in the last three decades, the recent downturn and increasing awareness of the social consequences of foreign labor inputs have led to serious rethinking by the PAP government on the prevailing Singapore economic model. With acknowledgment that continuous investments in improving the workforce is vital to Singapore's future, the need to recognize the impact of a changing Singaporean labor workforce and its implications to the future is warranted. The shift has indeed already occurred, as early as 1998, when the Singapore's Industry 21 Master Plan identified scaling up the nation to embrace knowledge-intensive and high value-added manufacturing services.

\section{Income Inequalities and Consequences for Social Cohesion}

With the success that Singapore has earned in gaining all the accoutrements of a first world nation, it also has inherited for itself the typological features of global cities: increasing presence of "highly-skilled and highly-paid expatriate workers and the rise in low-skilled immigrant labor" (Baum, 2003, p. 224) and, thus, increased "wage inequality" (K. W. Ho, 2007, p. 44). This has resulted in the emergence of a "dualistic labor market" and an increased disparity between "high and low-income earners" (Peebles \& Wilson, 2002, p. 263). A worrisome trend is the Gini coefficient, ${ }^{8}$ which has manifested a continuing increase in income inequalities from 2000 until 2010, registering 0.430 and 0.452 , respectively (Singapore Statistics, 2010). 


\section{Need to Produce Imaginative and Creative School Leavers}

Singapore's success in enhancing a pool of skilled workers from 1965 to 1990 is one of the pillars that continues to prop up the nation's economy. With the incessant international competition for nations to become KBEs, Singapore continues to ensure that its investments in human capital are at the forefront of the nation's policy options. The PAP-led government realizes that to retain its high rankings as a globally competitive economy, it needs its workers to embrace lifelong learning and, more important, retool themselves to acquire higher-level skills.

\section{Singapore City-State's Tactical Globalization Response: The TSLN Framework}

The rapid pace of economic globalization, the challenges that it brought for economic competitiveness in the 1980s, and its impact on education were noted by Singapore's planners. Although decentralization and variety were created through the independent schools initiative beginning in the late 1980s, the MOE acknowledged that Singapore education outcomes still lacked such qualities as enhanced imagination, creativity, and enterprise needed for the 21 st century; thus, the TSLN framework was launched:

A nation's wealth in the 21 st Century will depend on the capacity of its people to learn. Their imagination, their ability to seek out new technologies and ideas and to apply them in everything they do will be the key source of economic growth. Their collective capacity to learn will determine the well-being of a nation. (C. T. Goh, 1997, p. 1)

\section{Creating an Economic Niche: Research and Development}

The TSLN outlined the framework of intensive R\&D (research and development) as one of the pathways to prepare the nation for the 21st-century challenges: "We cannot assume that what has worked well in the past will work for the future. The old formulae for success are unlikely to prepare our young for the new circumstances and new problems they will face" (C. T. Goh, 1997, p. 3). Given the limitations of a small labor force, Singapore has deliberately pursued an aggressive $\mathrm{R} \& \mathrm{D}$ agenda, creating for itself specialized niches in high-value manufacturing. In 2008 alone, the nation spent SGD $\$ 7.13$ billion dollars (US\$5.75 billion), a 12.4\% jump from the previous year in its gross expenditure on R\&D. This increase represented 2.66\% of GDP (Agency for Science Technology and Research, 2009). These are significant steps toward earmarking gross expenditure on R\&D to be $3 \%$ of GDP by 2010. Although these examples highlight how Singapore is actively exploring the judicious use of its education and training policy and processes to address threats to its economic niche, the more critical question is whether investments in $R \& D$ will 
be enough or will need coupling with more imaginative responses to building up innovation and entrepreneurial capacity.

\section{Highly Educated and Deeply Rooted Workforce for the 21st Century}

A highly educated workforce continues to be a response of the city-state amid challenges of the 21st century:

We must set up comprehensive mechanisms to continually retrain our workforce, and encourage every individual to engage in learning as a matter of necessity. Even the most well-educated worker will stagnate if he does not keep upgrading his skills and knowledge. (C. T. Goh, 1997, p. 10)

To make this happen, the MOE performs a dominant and strategic all-encompassing role as prime stakeholder, assuming the part of principal provider of resources, including those needed for the operations of schools and tertiary institutions in the country (Ministry of Finance, 2009). The PAP-led Singapore state realizes that to move higher in the value chain and accomplish its aspirations as a KBE, it needs to retrain and nurture all its citizens. Official Singapore policy has identified that as many Singaporeans as possible should "obtain a post-secondary education, whether it be for a certificate, diploma, or degree" (Shanmugaratnam, 2007a, p. 4).

Alongside investments in high-quality education, national educationthat is, the sense of identity and rootedness of Singaporeans- has also been identified as vital to its future as a nation: "We will also strengthen National Education, through formal lessons as well as experiences outside the classroom, so as to develop stronger bonds between pupils and a desire to contribute to something larger than themselves" (C. T. Goh, 1997, p. 9). The PAP government has recognized that preparing students and graduates for a postindustrial knowledge economy requires strengthening the bonds of social cohesion and active citizenship. National education highlights a strategic approach in preparing the education system to be locally rooted but attuned to global trends, clearly a proactive step toward producing citizen workers for a knowledge economy. Scholars have critiqued the uniquely Singapore style of active citizenship (Han, 2000), encouraging "positive and cooperative" (Rodan, 2004, p. 84) interactions among civic groups in the public and private sector while vigilantly disallowing dissent.

\section{Imaginative and Creative School Learners}

Note that the call for imaginative and creative students/graduates was a major departure from the conventional approach that Singapore had pursued since the early 1960s to the late 1990s, typified by efforts to ensure survival and efficiency through education (Y. S. Lee, 2006). The earlier era of Singaporean education featured a city-state that "had established itself as a strategic player not only in the workforce planning but also in the wider 
process of economic development" and invariably led to a situation where "government policy circles" nurtured a strong "belief in human capital theory, irrespective of any academic doubts that there might be of the matter" (Sharpe \& Gopinathan, 2002, p. 155).

The TSLN education strategies that have been adopted are geared toward the recognized needs of an innovation-driven KBE: a push toward more engaged learning, collaboration, autonomy, and creativity. The MOE has instituted reforms to create these "learning environments" where schools and systems are encouraged to move toward situations where students team up and acquire knowledge and skills in "open-ended" fashion (Gopinathan, 1999, p. 299). Similarly, the MOE introduced the "cluster schools" concept to enable sharing, and in 2009 it announced the creation of teacher development centers to promote greater teacher autonomy and professionalism. Funding has also been pumped into the school system to jump-start innovation, experimentation, and enterprise in schools through the School Innovation Fund (p. 300).

In its continuous attempts to address the challenges awaiting it, the system has been undergoing what seems to be constant upheaval. However, the accomplishments in maintaining a well-calibrated balance between education and labor market needs, as we explain subsequently, is now turning problematic.

Critical to the Singapore government's success has been the ability to adjust quite well to the challenges that the nation has faced. A distinguishing feature of the government is its adherence to "policy-oriented learning"that is, "an ongoing process of search and adaption motivated by the desire to realize core policy beliefs" (Sabatier, 1988, p. 160). In this case, the core policy beliefs shared by the Singapore government with respect to education and training remains as they were during its founding years: centralized meritocratic system of education "designed to promote social cohesion and produce a capable workforce through systematic skill formation strategies" (Gopinathan, 1999, p. 296).

Meritocracy as articulated by the MOE and Singapore's Public Service Commission quintessentially remains as "one of Singapore's fundamental values and critical success factors" (S. P. Goh \& Loh, 2008). As a result of this deeply entrenched belief, high-stakes testing ${ }^{9}$ persists and remains the most important indicator of educational competency in Singapore (Gregory \& Clarke, 2003; Y. K. Tan, Chow, \& Goh, 2008) alongside the government's active promotion of 21 st-century new economy competencies.

With the TSLN calling for learning cultures, greater professionalism, and autonomy, the PAP-led government has responded by continuing to place the highest premiums on high-stakes tests as evidence of meritocracy alongside the rhetoric of loosening up the educational system. This pragmatic stance of the Singapore city-state of adapting certain aspects of the education system on its own terms continues to the present with a host of complex and related issues. 


\section{How Do Singapore Teachers Make Sense of the TSLN?}

\section{Information Communication Technology Master Plans, 1997-2014}

The TSLN led to a number of initiatives-for example, a reduction of curriculum content, the widespread propagation of information communication technology (ICT), and the introduction of critical thinking skills in the curriculum. ICT is one of the "key contributors to Singapore's economic success," particularly in the manner that it has been strategically aligned and deployed "with the needs of the economy and society, as well as the coordinated efforts arising from the national ICT plans" (T. S. Koh \& Lee, 2008, p. 167) as a key lynchpin in achieving KBE status. Singapore initiated two ambitious master plans and has most recently jump-started a third, ${ }^{10}$ all of which were designed to harness the benefits of ICT in harmony with the development objectives of the nation. ICT use in classrooms and schools has been heralded as a potent way to promote enhanced, collaborative, and complex learning experiences among young students (Dede, 2000). The challenges of implementing radically new ICT-driven curriculum-integrating relatively untested innovations within unique contexts of schools while securing teacher collaboration and commitment-have been documented quite extensively (Dede, 2000).

The 2010 Global Information Technology Report indicates that Singapore placed second (down from first for the previous 3 years) and, more important, ranked first for two key readiness components: "quality of math and science education" and "quality of the educational system" (Dutta \& Mia, 2010, p. 285). In Singapore, there seems to be clear evidence of the widespread penetration of ICT in schools. However, with the use of micropolitics as an exploratory analytical lens, particularly in the way that "actors use formal and informal power to either achieve their desired goals or protect their interests" (Marsh, 2012, p. 165), the responses of Singapore teachers to the ubiquitous ICT policy reveal contradictions.

Ongoing studies conducted at Singapore's National Institute of Education since $2004^{11}$ suggest that underlying difficulties in implementation are prevalent in Singapore school practices, especially in the use of learning tools. Findings revealed that teachers primarily used ICT for presentation purposes: through use of PowerPoint (15.7\%) and the Internet (2.4\%). Students, however, made use of worksheets more than half the time $(51 \%)$ and ICT almost sparingly (Hogan et al., 2006). Notwithstanding evidence of widespread ICT presence as reported in the 2010 global report, teachers (and students) have arguably failed to harness the full potential of the technology.

A consistent theme that cuts across the TSLN and the first three master plans is what former prime minister C. T. Goh (1997) explicitly pointed out as the need to ignite true "passion for learning" among students in Singapore. He challenged the education system to go beyond knowledge "for the sake of getting good grades" and to embrace instead a continuous desire to gain 
knowledge "well after they leave school" (p. 3). This dilemma does not solely concern the students; in a much deeper way, it involves teachers as well.

Studies at the National Institute of Education's Centre for Research in Pedagogy and Practice, which has been investigating classroom practices in Singapore since 2004, reinforce the notion that Singaporean teachers persist with direct instruction and do not place much emphasis on harnessing ICT as a platform for teaching and promoting critical thinking. Hogan and colleagues (2006) reported,

Singapore teachers reported high levels of traditional pedagogy (e.g. drill and worksheets) and direct instructional behavior (e.g. management of student attention and behavior, structure and clarity of presentation, pacing) but relatively low levels of constructivist pedagogy (e.g. creative and critical thinking, integration of knowledge across disciplines). (p. 36)

These patterns reinforce the argument that teachers are reluctant or perhaps encounter implementation difficulties when embracing nontraditional pedagogy (i.e., ICT-intensive classes) and in trying to create classroom environments that are sites for critical thinking.

This supports findings from a 5 -year study ${ }^{12}$ that encompassed 8,000 participants and 12 schools, where empirical evidence reveals what teachers perceive as three obstacles in using ICT for learning and teaching: "(1) ICT-based lessons are time-intensive; (2) time allocated in the timetable for the lessons is insufficient; and (3) the use of ICT is not required in national examinations" (S. C. Tan et al., 2010, p. 3). The persistence of Singapore teachers' reliance on traditional pedagogy and direct instruction should be interpreted as a critical response to the comprehensive drive for ICT integration in schools advocated by the city-state. A more nuanced understanding of this teacher practice can be appreciated by taking into consideration the powerful impact of teachers' efficacy. ${ }^{13}$

Compared with other teacher variables (teacher qualification, experience, age and commitment), teacher efficacy was found to have the strongest and most consistent correlations with a wide range of instructional practices. (Hogan, 2006, p. 64)

In a demanding and time-pressured context where high-stakes test results for students' examinations are given such a high premium (Gregory \& Clarke, 2003), Singapore teachers choose to bank on their efficacy in teaching, as opposed to the dominant policy call for ubiquitous ICT use. Rather than adopt an untested approach of ICT use in the classroom and possibly face unknown risks within a context of high-stakes results, teachers respond by manifesting behavior that is not "motivated by the pursuit of achieving collective goals"; rather, they exercise their prerogative in "protecting their self-interest" by relying on their efficacy and thus exercising their "power" (Marsh, 2012, p. 167) in choosing conventional teaching approaches. This micropolitical perspective illustrates an example of how Singapore teachers 
exercise their political agency by employing "strategies and tactics to achieve their goals and protect their interests" (Blase \& Blase, 2002, p. 43) within the interstices of the globalization discourse highlighting a contested terrain in the implementation of education reforms. This exploratory inquiry sheds light on current research that highlights how political and sociocultural exigencies of education reform redefine teacher agency, particularly in classroom instruction and accountability:

One of the most powerful enduring elements of participants' agency was their unwillingness to change their identity as individuals working in a human-centered profession, which required making real connections with their students. (Lasky, 2005, p. 913)

In the same way that the Singapore city-state exercises tactical globalization in pursuing education and training policies amid globalization, Singapore teachers exercise their political agency by resisting the call to overhaul teaching and move toward more intensive ICT usage.

\section{GROW: Growth of Education Officers, Recognition, Opportunities and Well-Being}

In 2006, the MOE launched the GROW package-the Growth of Education Officers, Recognition, Opportunities and Well-Being-designed to strengthen teacher development and recognition. It earmarked US\$170 million (SGD $\$ 250$ million) to be spent in the next 3 years to "continue to attract, motivate and retain good teachers, capable school leaders and dedicated specialists" (p. 1). A year later, GROW 2.0 was launched with a commitment to pump in an additional "US\$261million (SGD\$380 million) each year onwards" (Shanmugaratnam, 2011, p. 5). In its efforts to maintain a highperforming educational system while being faced with the pressure to continue to attract the best and the brightest into teaching ${ }^{14}$ within a globalized and "extremely tight labor market," the MOE has identified that sustaining a "high performance culture in any knowledge-based profession" requires a "robust and fair system of appraisal and performance management" (Shanmugaratnam, 2007b, p. 4). It recognizes that in such a competitive global employment context, extrinsic rewards become its main "logic of action" or "the relationship between means and goals" (Bacharach \& Mundell, 1993, p. 427) in maintaining its competitive edge. Research conducted at the $\mathrm{Na}$ tional Institute of Education about motivations that drive beginning teachers toward the profession indicate very interesting results. ${ }^{15}$ Key findings from the study elaborate on the reasons why teacher trainees join the profession: intrinsic reasons ("to do with personal growth and working in a school environment"-50\%), altruistic reasons ("a liking for and desire to work with children and young people"-39.1\%), and extrinsic reasons ("relating to material benefits and job security"-9.9\%; Chong \& Low, 2009, p. 63). Teachers at the beginning of their careers in Singapore arguably respond to 
the dominant state discourse of extrinsic reward messages through an emerging identity driven primarily by altruistic and intrinsic rewards. Teachers at the beginning of their careers manifest a logic of action different from that of the city-state.

Micropolitics, defined as "the confluence of difference logics of action" (Bacharach \& Mundell, 1993, p. 432) within a system, becomes a powerful analytical tool in discovering the nuances of teachers behaviors within a dominant education context such as Singapore. Organizational politics can be seen as "the contest that occurs over various possible logics of action" (p. 428). Using the micropolitical perspective, one can therefore affirm that the contrasting logics of action of the city-state and teachers in relation to ICT usage and that the perceived rewards of teaching are specific manifestations of organizational politics in Singapore education. The article posits that in the drive of the Singaporean city-state toward becoming a KBE, teachers exercising their political agency "turned out to be the final policy makers, as evidence mounted that they could reshape or resist the intentions of policies adopted at higher levels" (Boyd, 1991, p. vii).

\section{How Do Singapore Students' Make Sense of the TSLN?}

One of the core messages of the TSLN is lifelong learning: the ability of Singaporeans to engage in knowledge acquisition that goes well beyond institutionalized education and through one's entire life:

The most important gift that we can give to our young and to prepare for their future is education. It's not just preparing them for a job, but learning to live a life, learning to deal with the world, learning to be a full person. (H. L. Lee, 2004)

The MOE's logic of action in achieving KBE status via the TSLN was through the adoption of lifelong learning. However, given the "intensely competitive" nature of the system and the fact that examinations serve as the "gateway to each level of education" (Gregory \& Clarke, 2003, p. 71), Singapore students face pressure in coping with the demands of education. With the advent of the dynamic forces of globalization and efforts to ensure that future generations embrace enduring principles of lifelong learning, Singapore youth reinterpret this message and pursue a contrasting logic of action. On the notions of lifelong learning, research at the National Institute of Education's Centre for Research in Pedagogy and Practice into student life pathways in Singapore since 2004 manifests the reinterpretation of the value of education among students.

It is clear that for the Primary and Secondary students in our study, education serves specific instrumental and economic goals. Among the P4 cohort, doing well in exams is the most important reason for why education is valued. This emphasis continues among the $\mathrm{S} 1$ cohort, but education is valued for its role in helping students secure a high paying job. (D. Hogan et al., 2007, p. 203) 
In relation to the use of ICT, key findings of an empirical evaluation of the third master plan shed valuable light: Students used ICT cooperatively merely for "task completion rather than collaboratively advance their understanding of the subject knowledge" (S. C. Tan et al., 2010, p. 3). Once again, there is divergence in the logics of action between the city-state's push for intensive ICT usage for collaborative learning and the way that students use ICT merely as an instrument toward task completion.

Using a micropolitical perspective in which students' interpretational responses are placed at the foreground highlights the divergence of imposed meanings of the dominant, as education is seen not as the idealized portable lifelong skill (i.e., learning about new things and about the future) as laid out in the TSLN roadmap but as a finite "means to an end" (i.e., getting a high-paying job and doing well in exams). Using the lens of micropolitics, one can argue that students within a high-stakes testing system prioritize their efforts toward achieving "their desired goals or protect their interests" (Marsh, 2012, p. 165).

Lee Kuan Yew stated that "we are of immigrant stock, having left a richer cultural, and psychologically more secure past, we have only the future to make something of, and that we have determined to do" (cited in K. Y. Lee, 1984, p. 194). This clarion call to create a history hinged on "the future" works well when rallying an impoverished population toward survival, sustainability, and progress. However, an unintentional drawback, as pointed out by a silent minority of critics, could be the absence of a sense of authentic and critical history effectively hampering efforts to break the binds of traditional and entrenched conformist thinking: "Singapore needs a stronger and critical historical discourse so that Singaporeans can have a deeper understanding of history, as the past is the foundation of individual and collective identity" (Wee, 2002, p. 228).

Another point of view is that the representations of Singapore are controlled by the ruling elite. In reference to an incipient civil society movement in Singapore, the need for a critical history becomes vital: "As long as history remains the PAP's exclusive prerogative, Singaporean civil society's own historical linkages will be denied in their own right" (Chng, 2002, p. 28). Singapore commentators have repeatedly harped on the very real limitations of creating a flourishing of civil society in Singapore (Zolo, 2004). Attitudes of the government, perceptions of lack of transparency, and fear have handicapped and "built barriers to civil society activism" (Singam \& Tan, 2002; Zolo, 2004). They have reiterated the vital importance of civil society in fostering mature political cultures, particularly in plural societies. With the discourse on history and the reins of national development (economic, historical, even cultural) firmly in the hands of the PAP government, the current "loose and inclusive definition of civil society is only indicative of its condition of being a 'work-in-progress' in Singapore" (Chng, 2002, p. 23). J. Tan and Gopinathan (2000) unequivocally suggest that the path to "true 
innovation, creativity, experimentation and multiple opportunities in education" would be accomplished only if and when the "state allows civil society to flourish and avoids politicizing dissent" (p. 10).

Scholarship in civic education and political socialization is replete with assertions that civic beliefs among the youth invariably become precursors of an active and vibrant civil society and are positively related to improved educational outcomes. Scholars in education, particularly developmental theorists, have provided empirical arguments about the importance of students experiencing critical differences or diversity during postsecondary education and, in the process, developing civic beliefs as contributors to educational outcomes (Jankowski, 2002).

Singapore's experience of critical discourse highlights tensions and dissonance. This dissonance is reflected by research findings at the Centre for Research in Pedagogy and Practice revealing postsecondary students' self-reports of selected measures of civic beliefs that "are both negative and significant" to a limited set of educational outcomes (Table 1; Hogan et al., 2006). Singapore's students performed well in selected educational outcomes, while interest for fostering civic beliefs is stunted. The negative correlation defies conventional argument theorizing that developing civic beliefs contributes to improved educational outcomes. A possible explanation for this could be found in the way that Singapore has engendered a unique form of active citizenship (Rodan, 2004), emphasizing notions of the good citizen while downplaying the facets of a highly critical citizen (Sim, 2008). An important issue to consider is the implications of this dissonance to current classroom practices and to the continuing socialization experiences of Singaporean students.

Table 1. Correlations of Civic Commitments/Beliefs to Student Outcomes

\begin{tabular}{lcccccc}
\hline & & & \multicolumn{2}{c}{$\begin{array}{c}\text { Self-Reported } \\
\text { Results }\end{array}$} \\
\cline { 5 - 7 } Commitments/Beliefs & $\alpha$ & $M^{\text {a }}$ & & $P S L E^{\mathrm{b}}$ & O Level $^{\mathrm{c}}$ \\
\hline $\begin{array}{l}\text { Commitment to meritocratic principles of social } \\
\text { inequality }\end{array}$ & .859 & 3.63 & $-0.124^{*}$ & $-0.079^{*}$ \\
$\begin{array}{l}\text { Sense of civic membership: sense of pride in and } \\
\text { attachment to Singapore as a nation }\end{array}$ & .837 & 3.95 & $-0.069^{*}$ & $-0.072^{*}$ \\
\hline
\end{tabular}

Note. Data based on a stratified random sample of 27 post-secondary institutions (12 Junior colleges, 5 polytechnics and 10 Institutes of education). For more information, see Hogan et al. (2006).

aScale: 1 = very low, 5 = very high.

bThe Primary School Leaving Examination is the high-stakes final examination that Primary 6 students take at the end of primary schooling, just before they start secondary schooling.

cThe General Certificate of Education Ordinary Levels ( $O$ Level) is usually set by the University of Cambridge Local Examination Syndicate and taken by the students at the end of their fourth or fifth year in secondary school.

${ }^{*} p<.01$. 


\section{Discussion}

Using deeply perspectival constructs of stakeholders' interpretation of the TSLN policy reveals contrasting sense-making responses. The PAP-led government response highlights a trait that it has consistently employed through its emphasis on "constant learning and upgrading" as a fundamental basis for its "comparative advantage" (Ashton et al., 1999, p. 26). This is seen at several levels—at the Economic Development Board, which positions itself as a learning organization (Ashton \& Sung, 2000, p. 210), and at the MOE, as the paramount agent of education reform, adopting features of a learning organization. Reform initiatives have, to some extent, begun to reshape the culture of learning in the school system, but they have also put into perspective contradictions experienced by teachers and students.

\section{Tactical Globalization: Adaptation Versus Learning}

There is a growing tension on the limitations inherent in learning organizations and a move toward a more holistic perspective that encompasses not only aspects of improved learning practices but, more important, issues that touch on more comprehensive reforms. This is one of the serious challenges that face the Singapore city-state and one of its key institutions-the MOE and its schools-in preparing the nation for an uncertain future: the extent of comprehensive reforms that it is willing to undertake. Recognizing the entrenched traditional mind-sets inherent in the education system and the need for creativity and innovation, the education system itself must have the capacity to engage in learning, which implies that "the organization's members are induced to question earlier beliefs about the appropriateness of ends of action, and to think about the selection of new ones, to revalue themselves" (Haas, 1991, p. 73). The organizational learning required is not merely adaptation that is "muddling through" (p. 75). Gopinathan (2007) points out a more profound extent of the necessary changes:

At the school level, change, while it is occurring, is not yet fundamentally changing pedagogy and practice. Teachers having to cope with large classes, a content dominated curriculum and high stakes examinations have taken on initiatives like thinking skills but rather than allow for a reconceptualization of practice have, in many cases, bolted on acceptable elements and routinized procedures-a technique-oriented view of creativity prevails. (p. 67)

What is required by the education system and the schools is a bold attempt to embrace new paradigms and attain disciplinarity; schools have to become knowledge-creating communities (Hogan \& Gopinathan, 2008). Achieving deep learning and knowledge creation and not mere adaptation requires grappling with the fundamental issue of whether it would be "possible to bring about changes in teachers' beliefs, values, and attitudes con- 
cerning such matters as epistemology, the roles of teachers, and the nature of teaching and learning" (p. 372).

The PAP-led Singapore government has promulgated wide-ranging reforms in educational policy and practice designed to prepare the nation to be a KBE for the 21 st century. As dominant and principal stakeholder, the citystate responds to the challenges of globalization by continuing to redefine its identity as political enforcer where "national politics determine the content of local policies" (Gopinathan, 2001, p. 17).

Consistent with the characteristic of pragmatic enforcer, it has embraced the goal of achieving new economic competencies dealing with creativity and innovation while clinging to high-stakes testing as the prime yardstick of meritocracy. Furthermore, critical thinking and social cohesion have been identified as future desired goals at the same time that it continues to be reluctant to open up space for authentic civil society and dissent to be promoted.

This inquiry argues that the Singaporean city-state's deliberate policy choices, as reflected by its logics of action, point toward becoming a KBE that regards education primarily from a functionalist viewpoint. This type of KBE emphasizes aspects of a "knowledge economy" reflecting "an ideological extension of the neoliberal paradigm of globalization, where the term stands for a 'stripped down' functionalist view of education in service of the multinationals" (Peters, 2001, p. 13). This is opposed to the KBE that focuses on the creation of a "knowledge society" allowing for the "reinvention of education as a welfare right and the recognition of knowledge rights as a basis for social inclusion and informed citizenship" (p. 13). The Singapore KBE model that is skewed more toward a "knowledge economy" mold is the source of political tension from two key stakeholders of education: teachers and students.

\section{Tactical Globalization Responses: Teachers' Political Agency, Students' Disjunctured Identities}

The city-state, as represented by the MOE, has pursued specific logics of action to navigate the challenges of globalization anchored firmly on the model of a knowledge economy. The teachers' logics of action contrast those of the state. Responding to the dominant ICT policy push from the MOE, on one hand, and a prevailing context for high-stakes performance, on the other, teachers exercise political agency and respond by finding motivation through nonmaterial benefits and by exercising autonomy in the classroom.

The TSLN identified ICT-savvy, lifelong learners deeply rooted in Singapore as the future workforce in a 21 st-century Singapore KBE. Thus, the MOE's logic of action has consistently adhered to its specific mode of meritocracy. Using the lens of micropolitics, one sees that the students' sensemaking responses reveal disjunctured identities wedged between the push for globalized education and local rootedness. Students value education merely 
as an instrumental tool while experiencing disconnection between so-called 21 st-century educational outcomes and fostering civic beliefs and practices. Interestingly, this problematic linkage poses interesting questions to current national socialization policies and has implications not only to the changing identities of students but to the future of an emerging Singapore nation.

\section{Achilles Heel of the Strong State: Seeking Control During Uncertain Times}

Comparing emerging responses of stakeholders making sense of the political and tactical globalization of the dominant Singapore government provides analytical illumination in recognizing how strong states face contradictory responses. Active interpretational responses viewed from a micropolitical perspective of key stakeholders highlight the sites of political tension occurring amid the dynamic forces of globalization. For critical studies in education, the case of Singapore provides an exploratory account of the multilayered perspectival constructs of key stakeholders in education:

From the dominant city-state viewpoint: a vast array of resources in mobilizing tactical globalization through educational policies and the challenge of continuing to pragmatically adapt or embrace fundamental change.

From bighly competent, intrinsic, and altruistic corps of teachers: emerging contestations represented by political agency in the classrooms and a professional identity hinged on intrinsic and altruistic reasons.

From a future workforce made up of bigh-performing students: undeveloped civic capacities alongside education valued primarily from an instrumental perspective.

The systemwide change sought after by the education system to prepare itself for the 21st century provides an interesting reflective study on the notion of KBEs. Singapore's characteristic of constant learning and upgrading - coupled with its unrivaled record of policy implementation continuity and solidly supported by the nation's unique strength in governance-paints a tense future.

The Singapore government, not usually known as an education system open to uncertainties, faces uncharted territory as dynamic forces of globalization, from within and from outside, continue to shape a contested landscape. Analysis of future trajectories of the state and other key stakeholders focusing on their responses from a micropolitical lens could provide alternative perspectives in a contested globalized landscape. As revealed in this exploratory inquiry, the Singapore city-state' s aspirations of becoming a KBE that adheres much more to a "knowledge economy" rather than a "knowledge society" model continues to be the site of political contestation among education stakeholders. IJER 


\section{Notes}

1. See, for example, the 21st Century Skills, Education and Competitiveness (Partnership for 21st Century Skills, 2008).

2. For more information, see Riley and Torrance (2003).

3. The People's Action Party has been the dominant party in Singapore since 1963. In the 2011 Singapore general election, the party garnered 81 of the total 87 parliamentary seats while receiving $60.14 \%$ of the total votes cast -its lowest percentage share in history. For more information, see Singapore Elections Department (2011).

4. This globalization index is composed of four key components of global integration: (1) trade and investment flows, (2) movement of people across borders, (3) volume of international telephone calls and Internet usage, and (4) participation in international organizations. For more information, see http://www.atkearney.com/index.php/Pub lications/globalization-index-data-2007.html.

5. "Administrative" and "developmental state" have been used to describe the strong city-state of Singapore that has been led for the past 40 years-or much of its modern history - by the politically dominant People's Action Party. For more information, see http://www.pap.org.sg/.

6. Yet, such is the growth in the economy and its well-earned reputation for efficiency that education expenditure is less than $4 \%$ of gross domestic product.

7. The main ethnic groups for the Singapore resident population (including Singaporean citizens and permanent residents) are Chinese (74.1\%), Malays (13.4\%), Indians (9.2\%), and others (3.3\%). More information can be obtained from Singapore Statistics.

8. The Gini coefficient, a summary measure of income inequality, measures employed households in Singapore.

9. The Primary School Leaving Examination is a high-stakes national examination taken at Year 6 by all students completing the final year of primary school education in Singapore. The examination is designed to

1. gauge of how much our students have mastered our curriculum objectives, 2 . benchmark of our students' academic attainments compared to that in other systems around the world, 3. form of feedback to parents and the public on our students' academic attainments, and 4 . source of pertinent information for placing our students in the appropriate course of study at the next stage of education.

For more information, see Fong, Lim, Leng, and Leng (2007).

10. The master plans for information communication technology (ICT) in education drive the use of ICT in education. The underlying philosophy of the master plans is that education should continually anticipate the needs of the future and prepare pupils to meet those needs. For more information, see Ministry of Education (2008).

11. The findings discussed in this article are derived from Panel 6 of the Centre for Research in Pedagogy and Practice's CORE Research Project initiated in 2004. Panel 6 is a longitudinal study of approximately 32,000 students randomly stratified from three cohorts (primary, secondary, and postsecondary) coming from 115 institutions. These respondents were asked to accomplish online surveys lasting about 30 to 45 minutes. These surveys attempted to capture different self-reported measures of young peoples' beliefs and practices. The Panel 6 survey focused on students' life experiences; processes of development; the formation of "institutional capacities" or "capitals" (educational, economic, social, cultural, civic, intercultural); institutional 
participation and attainments (school, work, community); subjective well-being; and life goals, plans, choices, and pathways. For more information see Hogan et al. (2007). 12. The 2009 Instrumentation and Baseline Study was designed to evaluate the implementation of the third master plan and its impact on Singapore schools. The data-gathering process for this baseline study consisted of repeated cross-sectional surveys complemented by case studies of selected schools. This study is part of a 5-year research undertaking that will tap more than 8,000 participants and focus on in-depth case studies of 12 schools. The study was undertaken by a team from the National Institute of Education, Nanyang Technological University, Singapore. For more information, see S. C. Tan and colleagues (2010).

13. The model of teacher efficacy in the Centre for Research in Pedagogy and Practice's Core Study is defined as teachers' self-perceived competence in three key tasks: instructional strategies, classroom management, and student engagement. For more information, see Hogan and colleagues (2007).

14. All teachers in Singapore are recruited from the top $30 \%$ of the high school academic cohort. For more information, see Auguste, Kihn, and Miller (2010).

15. The National Institute of Education's Longitudinal Research Project (20042010) on Initial Teacher Preparation Programs tracked the development of teacher trainees (605 in total) from Year 1 to Year 3 . The project measures the motivation factors for teacher trainees and serves as a baseline study to further inform and improve current preparation programs. In Singapore, the National Institute of Education is the sole teacher-training institute; thus, all teachers aspiring to be part of the profession obtain their training and credentials at the institute. For more information, see Chong and Low (2009).

\section{References}

A. T. Kearney, Foreign Policy, \& Chicago Council for Global Affairs. (2008). The 2008 Global Cities Index. Retrieved from http://ForeignPolicy.com

Agency for Science Technology and Research. (2009). Singapore reported increased R\&D intensity in 2008 with R\&D expenditure of S\$7.13 Billion and $2.77 \%$ of GDP. Retrieved from http://www.a-star.edu.sg/Portals/0/media/Press\%20Release/20091223_RnD_ Survey_2008_Final.pdf

Appadurai, A. (1990). Disjuncture and difference in the global cultural economy. Public Culture, 2, 1-24.

Ashton, D., Green, F., James, D., \& Sung, J. (1999). Education and training for development in East Asia: The political economy of skill formation in East Asian newly industrialised economies. New York: Routledge.

Ashton, D., \& Sung, J. (2000). Maximizing human potential and the process of economic growth in Singapore. In D. Herschbach \& C. Campbell (Eds.), Workforce preparation: An international perspective (pp. 196-212). Ann Arbor, MI: Prakken.

Auguste, B., Kihn, P., \& Miller, M. (2010). Closing the talent gap: Attracting and retaining top-third graduates to careers in teaching. In An international and market research-based perspective. Sydney, Australia: McKinsey.

Bacharach, S., \& Mundell, B. (1993). Organizational politics in schools: Micro, macro and logics of action. Educational Administration Quarterly, 29(4), 423-452.

Ball, S. (1994). Micropolitics of Schools. In T. Husen \& T. N. Postlethwaite (Eds.), The international encyclopaedia of education (2nd ed., pp. 3821-3826). Oxford, England: Pergamon. 
Baum, S. (2003). Social and economic restructuring and the new economy in Singapore. In T. Scrase, T. J. M. Holden, \& S. Baum (Eds.), Globalization, culture and inequality in Asia (pp. 215-284). Melbourne, Australia: Trans Pacific Press.

Beaton, A. E., Martin, M. O., Mullis, I., Gonzales, E. J., Smith, T. A., \& Kelly, D. L. (1996). Science achievement in the middle school years: IEA's Third International Mathematics and Science Study. Chestnut Hill, MA: Boston College, TIMSS \& PIRLS International Study Centre.

Blase, J., \& Blase, J. (2002). The micropolitics of instructional supervision: A call for research. Educational Administration Quarterly, 38(1), 6-44.

Boyd, W. (1991). Foreword. In J. Blase (Ed.), The politics of life in schools: Power, conflict and cooperation (pp. vii-ix). Newbury Park, CA: Sage.

Burbules, N., \& Torres, C. (2000). Globalization and education: An introduction. In N. Burbules \& C. Torres (Eds.), Globalization and education: Critical perspectives (pp. 1-26). New York: Routledge.

Chan, H. C. (1997). Politics in an administrative state: Where has the politics gone? In J. H. Ong, C. K. Tong, \& E. S. Tan (Eds.), Understanding Singapore society (pp. 294-306). Singapore: Times Academic Press.

Chang, H. Y. J. (2003). Culture, state and economic development in Singapore. Fournal of Contemporary Asia, 33(1), 85-105.

Chia, S. Y. (2001). Singapore: Towards a knowledge-based economy. In S. Masuyama, S. Y. Chia, \& D. Vandenbrink (Eds.), Industrial restructuring in East Asia: Towards the 21st century (pp. 169-208). Singapore: Institute of Southeast Asian Studies.

Chng, N. R. (2002). Fragrance and fragments of civil society: Reclaiming history. In C. Singam \& C. K. Tan (Eds.), Building social space in Singapore: The Working Committee's initiative in civil society activism (pp. 19-39). Singapore: Select.

Chong, S., \& Low, E. 1. (2009). Why I want to teach and how I feel about teaching: Formation of teacher identity from pre-service to the beginning teacher phase. Educational Research for Policy and Practice, 8(1), 59-72.

Dale, R., \& Robertson, S. (2002). The varying effects of regional organizations as subjects of globalization of education. Comparative Education Review, 46(1), 10-36.

Dede, C. (2000). Emerging influences of information technology on school curriculum. Fournal of Curriculum Studies, 32(2), 281-303.

Dutta, S., \& Mia, I. (Eds.). (2010). The global information technology report 2009-2010: ICT for sustainability. Geneva, Switzerland: World Economic Forum and INSEAD.

Fong, S. Y., Lim, R, Leng, N. S., \& Leng, O. A. (2007). PSLE seminar. Singapore: Singapore Examinations and Assessments Board.

Goh, C. T. (1997, June). Shaping our future: Thinking schools, learning nation. Speech by PM Goh Chok Tong.

Goh, S. P., \& Loh, N. S. (2008, 10 September). Equal chances for all. Straits Times.

Gopinathan, S. (1999). Preparing for the next rung: Economic restructuring and educational reform in Singapore. Fournal of Education and Work, 12(3), 295-308.

Gopinathan, S. (2001). Challenges facing the Singapore education system today. In J. Tan, S. Gopinathan, \& W. K. Ho (Eds.), Macro-policy: Globalisation, the state and education policy in Singapore (pp. 3-17). Singapore: Prentice Hall.

Gopinathan, S. (2007). Globalisation, the Singapore developmental state and education policy: A thesis revisited. Globalisation, Societies and Education, 5(1), 53-70.

Gregory, K., \& Clarke, M. (2003). High-stakes assessment in England and Singapore. Theory Into Practice, 42(1), 66-74. 
Haas, E. (1991). Collective learning: Some theoretical speculations. In G. Breslauer \& P. Tetlock (Eds.), Learning in U.S. and Soviet foreign policy (pp. 62-99). San Francisco: Westview.

Hales, M., King, S., \& Pena, A. M. (2010). The urban elite: The A. T. Kearney Global Cities Index 2010. Chicago: A. T. Kearney.

Han, C. (2000). National education and "active citizenship": Implications for citizenship and citizenship education in Singapore. Asia Pacific fournal of Education, 20(1), $63-72$.

Hay, C. (2002). Globalisation as a problem of political analysis: Restoring agents to a "process without a subject" and politics to a logic of economic compulsion. Cambridge Review of International Affairs, 15(3), 379-392.

Ho, K. L. (2000). Citizen participation and policy making in Singapore: Conditions and predicaments. Asian Survey, 40 (3), 436-455.

Ho, K. W. (2007). Wage inequality, intergenerational mobility and education in Singapore. Ethos (3), 43-47.

Hogan, D. (2006, May). Education and the pursuit of happiness in Singapore: Keynote address to the ERAS conference. Paper presented at the Educational Research Association of Singapore, Singapore.

Hogan, D., \& Gopinathan, S. (2008). Knowledge management, sustainable innovation, and pre-service teacher education in Singapore. Teaching and Teacher Education, 14(4), 369-384.

Hogan, D., Kramer-Dahl, A., Kang, T., Koh, K., Shun, L., \& Liau, A. (2007). CRPP core research program. In D. McInerney \& A. Liem (Eds.), Progress report, year three. Singapore: National Institute of Education, Centre for Research in Pedagogy and Practice.

Hogan, D., Luke, A., Kramer-Dahl, A., Kang, T., Koh, K., Shun, L., \& Liau, A. (2006). CRPP core research program. In R. Abdul Rahim \& D. Kwek (Eds.), Progress report, year two. Singapore: National Institute of Education, Centre for Research in Pedagogy and Practice.

Jankowski, M. (2002). Minority youth and civic engagement: The impact of group relations. Applied Developmental Science, 6(4), 237-245.

Koh, A. (2010). Tactical globalization: Learning from the Singapore experiment. Bern, Switzerland: Lang.

Koh, T. S., \& Lee, S. C. (2008). Information communication technology in education: Singapore's ICT masterplans 1997-2008. Singapore: World Scientific.

Lasky, S. (2005). A sociocultural approach to understanding teacher identify, agency and professional vulnerability in a context of secondary school reform. Teaching and Teacher Education, 21(8), 899-916.

Lee, H. L. (2004). National Day rally speech of PM Lee Hsien Loong 22 August 2004 at the NUS University Cultural Centre. Singapore: Ministry of Information, Communication and the Arts.

Lee, K. Y. (1984). Appendix: Interview with PM Lee. In R. Vasil (Ed.), Governing Singapore. Singapore: Eastern Universities Press.

Lee, K. Y. (1999). Speech by Senior Minister Lee Kuan Yew during the parliamentary debates on Singapore 21 on May 6, 1999. Singapore.

Lee, Y. S. (2006). Speech of Mr. Lee Yi Shan, minister of state for trade and industry at the opening ceremony of the Asia Study Visit for African Policy Makers. Singapore: Ministry of Trade and Industry. 
Marsh, J. (2012). The micropolitics of implementing a school-based bonus policy: The case of New York City's compensation committees. Educational Evaluation and Policy Analysis, 34(2), 164-184.

Martin, M., Mullis, I., Gonzales, E., \& Chrostowski, S. (2003). Executive summary. Boston: Boston College, TIMSS \& PIRLS International Study Centre.

Ministry of Education. (2006). MOE unveils \$250M plan to boost the teaching profession. Singapore: Author.

Ministry of Education. (2007). Government recurrent expenditure on education. Singapore: Author. Retrieved from http://www.moe.gov.sg/education/education-statistics-digest/online-interactive/resources/government-expenditure/

Ministry of Education. (2008). MOE launches third masterplan for ICT in education. Retrieved from http://www.moe.gov.sg/media/press/2008/08/moe-launches-thirdmasterplan.php

Ministry of Education. (2009). 2009 education statistics digest. Singapore: Author.

Ministry of Finance. (2009). Social development. Retrieved from http://www.mof.gov. sg/budget_2010/expenditure_overview/moe.html

Ministry of Trade and Industry. (1998). Committee on Singapore's competitiveness. Singapore: Author.

Montsion, J. M. (2009). Relocating politics at the gateway: Everyday life in Singapore's global schoolhouse. Pacific Affairs, 82(2), 637-656.

Mullis, I., \& Martin, M. (2007). Overview of PIRLS 2006 results. Boston: Boston College, TIMSS \& PIRLS International Study Centre.

Mullis, I., Martin, M., Beaton, A., Gonzalez, E., Kelly, D., \& Smith, T. (1997). Mathematics achievement in the primary school years: IEA's Third International Mathematics and Science Study (TIMSS). Boston: Boston College, TIMSS \& PIRLS International Study Centre.

Partnership for 21st Century Skills. (2008). 21st century skills, education and competitiveness: A resource and policy guide. Tucson, AZ: Partnership for 21 st Century Skills.

Peebles, G., \& Wilson, P. (2002). Economic growth and development in Singapore. Northampton, MA: Elgar.

Peters, M. (2001). National education policy constructions of the "knowledge economy": Towards a critique. Fournal of Educational Enquiry, 2(1), 1-22.

Phang, S. Y. (2000). How Singapore regulates urban transportation and land use. In Y. Shahid, W. Wu, \& S. Evenett (Eds.), Local dynamics in an era of globalization: 21 st century catalysts for development (pp. 159-163). New York: Oxford University Press.

Reyes, V. (2010). The Philippine Department of Education: Challenges of policy implementation amidst corruption. Asia Pacific Fournal of Education, 30(4), 381-400.

Riley, K., \& Torrance, H. (2003). Big change question: As national policy makers seek to find solutions to national education issues, do international comparisons such as TIMSS and PISA create a wider understanding, or do they serve to promote orthodoxies of international agencies? Fournal of Educational Change, 4(4), 419-425.

Rodan, G. (2004). Transparency and authoritarian rule in Southeast Asia: Singapore and Malaysia. London: RoutledgeCurzon.

Sabatier, P. (1988). An advocacy coalition framework of policy change and the role of policy-oriented learning therein. Policy Sciences, 21, 129-168.

Shanmugaratnam, T. (2007a). Budget speech 2007. Retrieved from http://www.singaporebudget.gov.sg/budget_2007/budget_speech/index.html 
Shanmugaratnam, T. (2007b). Speech by Mr. Tharman Shanmugaratnam, minister for finance and minister for education at the 10th Appointment Ceremony for Principals at the Shangri-la Hotel, 28 December 2007.

Shanmugaratnam, T. (2011). Expenditure overview for the Ministry of Education based on the 2011 budget. Retrieved from http://www.singaporebudget.gov.sg/budget_20011/budget_speech/index.html

Sharpe, L., \& Gopinathan, S. (2002). After effectiveness: New directions in the Singapore school system? Fournal of Education Policy, 17(2), 151-166.

Sim, J. (2008). What does citizenship mean? Social studies teachers' understandings of citizenship in Singapore schools. Educational Review, 60(2), 253-266.

Singam, C., \& Tan, C. K. (2002). Available spaces, today and tomorrow. In Building social space in Singapore: The Working Committee's initiative in civil society activism (pp. 155-174). Singapore: Select.

Singapore Elections Department. (2011). Total votes cast for general election 2011. Singapore: Author.

Singapore Statistics. (2010). Key household income trends, 2010. Policy Sciences, pp. $1-14$.

Singapore Statistics. (2011a). Gross domestic product. Retrieved from http://www.singstat.gov.sg/stats/themes/economy/hist/gdp1.html

Singapore Statistics. (2011b). Literacy and education. Retrieved from http://www.singstat.gov.sg/stats/keyind.html

Tan, J., \& Gopinathan, S. (2000). Education reform in Singapore: Towards greater creativity and innovation? NIRA Review, 7(3), 5-10.

Tan, S. C., Chai, C. S., Lee, C. B., Teo, K. G. T., Chen, W., Koh Hwee Ling, J., ... Cheah, H. M. (2010). Evaluation of implementation of the IT Masterplan 3 and its impact on singapore schools: Instrumentation and baseline study (Research Brief No. 11001). Singapore: National Institute of Education.

Tan, Y. K., Chow, H. K., \& Goh, C. (2008). Examinations in Singapore: Change and continuity 1891-2007. Singapore: World Scientific.

Wee, C. J. W. L. (2002). National identity, the arts and the global city. In D. da Cunha (Ed.), Singapore in the new millennium: Challenges facing the city state (pp. 221-242). Singapore: Institute of Southeast Asian Studies.

World Economic Forum. (2009). The global competitiveness report 2009-2010. Geneva, Switzerland: World Economic Forum.

Zolo, D. (2004). The "Singapore model": Democracy, communication, and globalization. In K. Nash \& A. Scott (Eds.), The Blackwell companion to political sociology (pp. 407-417). Malden, MA: Blackwell.

Dr. Vicente Chua Reyes, $7 r$ is a Lecturer with the School of Education, University of New England, Australia. Address correspondence to Vicente Chua Reyes 7 r., School of Education, University of New England, Armidale, NSW Australia 2351. E-mail: vicente.reyes@une.edu.au.

S. Gopinathan is a Professorial Fellow, National Institute of Education, Nanyang Technological University, Singapore. 